\title{
濃アルカリ溶液抽出による赤松サルファイト・パルプのヘミセルロース
}

(昭 和 36 年 9 月 30 日 受 理)

森田栄太 郎*

\begin{abstract}
赤松サルフォイト・パルプを $4 \%$ オルトホウ酸を含む $17.5 \%$ 水酸化ナトリウム扰よび $20 \%$ 水酸化カリウムで抽出 し，フェーリング液によるマンナンの単㕍を行ない，その構成単糖の検出およびその組成の決定を行なった。グルコ一 ス, マンノース, キシロースの 3 単糖が検出され，そのグルコースとマンノースの含量比は $17.5 \%$ 水酸化ナトリウム抽 出による場合は 1.6 1.9 で，20\% 水酸化カリウム抽出による場合は 2.5 で，アルカリ濃度の増加または抽出時間の延 長にしたがい, マンノースの含量が高くなる傾向を認めた。キシロースは $15 \sim 55 \%$ 混入されて分離され，キシランを含 むマンナンを酢化して，キシロースの含量を减少させることができた。この場合のグルコースとマンノースの含量比は 1.6 であった。またこの酢化物にはラムノースが含まれていることをペーパークロマトグラフィーで認めた。 dimethylsulfoxide で赤松パルプを処理して，加水分解産物として多量のキシランと少量のグルコース拉よびウロン酸が榆出され た。ウロン酸はペーパークロマトグラフィーの方法ではガラクッロン酸であると推定される。
\end{abstract}

\section{1 緒言および考察}

著者は先に ${ }^{1)}$ 赤松のサルファイト・パルプの $3 \sim 8 \%$ 水酸化ナ トリウム抽出液中には，マンノースとグルコースの含量比がほぼ 1.6 の組成をるつグルコ・マンナンが存在することを認めたが, この比は他の針葉樹材パルプに含まれているグルコ・マンナンに 比較していちじるしくマンノースの含量が低い。このほかに赤松 パルプにはな嫦法では抽出の困難なマンナン類の存在が予想さ れるので，ょり濃厚なアルカリ溶夜を用いて抽出を行ない，赤松 パルプのーミセルロース成分に新しい知見を加えようとした。

3〜4\% のオルトホウ酸を含むアルカリ溶液には，アルカリの みの溶液よりも炭水化物が抽出され易いことが知られているの で2), 赤松サルフフイト・パルプを $4 \%$ オルトホウ酸を含む 17.5 \% 水酸化ナトリウム拉よび $20 \%$ 水酸化カリウムを用いて抽出 し, 前報1)に準じてフェーリング溶液によるマンナンの単離を行 ない, その構成単糖の検索およびその組成の決定を行なった。 $17.5 \%$ 水酸化ナトリウムによる抽出の場合には, マンノースと グルコースとの含量比は 1.6〜1.9, 20\% 水酸化カリウムによる 抽出物ではこの值が 2.5 であり，アルカリ濃度の増加または抽出 時間の延長にしたがい, マンノースの含量が高くなる傾向を認め た。しかし，その比はな拉くの針葉樹材パルプに比較して依然 として低い值である。また前報と同様, このグルコ・マンナンに はキシランが含まれて分離された。

赤松パルプのマンナンの大部分はパルプの表面に近い非結晶領 域にあるが，少量は結晶領域にも存在するふ。したがってアルカ リで抽出されにくいマンナンのみが $\alpha$-セルロース中に残存し, そのためにマンノース量が他の針葉樹材のるのより小であるのか も知れない。20\% 水酸化カリウムを使用して抽出したマンナン のマンノース含量比は松崎ら゙) が，かつて赤松パルプを $17.5 \%$ 水酸化ナトリウムで抽出してえたマンナンとほぼ一致した值を示 した。

dimethyl sulfoxide を使用して赤松パルプを処理すると, キシ

* 九州工業大学工業化学科 : 戸畑市中原.

1) 森田, 工化 65, 106 (1962).

2) J. K. N. Jones, L. E. Wise, J. P. Jappe, Tappi 39, 139 (1956).

3）山田, 工化 62, 443 (1959).

4) 松崎, 守屋, 祖父江, 工化 62, 258 (1959).
ランを主成分とする抽出物が得られるが，この場合にも加水分解 産物中に，少量のグルコース打よびウロン酸が認められ，マンノ 一スは認められないから，この抽出物にはキシランの外に一種の グルコサンが共存することが予想できる。ウロン酸はべーパーク ロマトグラフィーではガラクッロン酸と推定される $R_{\mathrm{f}}$ 值を示 し，キシロースと結合したアルドビウロン酸の存在が予想され， キシラン・ボリウロナイドとして存在するものでないかと考えら れる。

キシロース，グルコース，マンノースを含む画分を酢化すると， 酢化剤に可溶性の画分と不溶性のものとに別れ，前者はキシロ一 スの含有は小であるが, 後者には相当量のキシロースの存在がみ られる。しかし両者ともマンノースとグルコースの組成はほぼ一 定で, その比は 1.6 となり, 前報1でえたグルコ・マンナンの組 成と一致する。この結果, 赤松パルプのへミセルロース中にはマ ンノース，グルコースが 1.6 の組成をもつグルコ・マンナンの存 在することが推定できる。

酢化剤に可溶な酢化物を与える多糖の 構成単糖にはグルコー ス, マンノース, キシロースの 3 単糖のほかに, ラムノ一スの存 在が認められたから，このメチルペントースも赤松パルプのヘミ セルロースの構成単糖の一つである。

\section{2 実験}

$2.14 \%$ オルトホウ酸を含む $17.5 \%$ 水酸化ナトリウムによ る赤松サルファイト・パル゚の抽出

赤松パルプ $149 \mathrm{~g}$ を $4 \%$ オルトホウ酸を含を $17.5 \%$ 水酸化 ナトリウムに室温で 1 時間浸漬したのち圧竹口過し，口液にフェ ーリング溶液を加えて，マンナン銅をえ，前報1)に準じて塩酸を 含むエタノールで分解し、エタノールで洗浄して塩酸を除いたの ち, $200 \mathrm{ml}$ の熱水で抽出した。抽出液を放冷すると沈䖉が生じ るので，これを別し，口液にエタノールを60\%になるまで加 え，生じる沈殿を $60 \%$ エタノール，95\%エタノール，エーテ ルで順次洗浄し，白色沈殿物 $0.2 \mathrm{~g}$ をえて，これを画分（I）と した。熱水抽出液を放冷して生じる白色沈殿は $2.1 \mathrm{~g}$ で，画分 （II）とした。

熱水に不溶部は $10 \%$ 水酸化ナトリウムにふたたび溶解し，フ ェーリング液を加えてふたたびマンナン銅を沈殿させ，前記と同 様にして脱銅し，脱酸し，洗浄乾燥して白色の粉末 $3.1 \mathrm{~g}$ をえ 
た。これを画分（III）とした。前報1の方法で算出した画分（II） 扣よび（III）の平均重合度は，それぞれ 28 および 32 であった。

画分（I），（II）および（III）は加水分解して，構成単糖とそ の組成の決定を行なった。加水分解は画分（I）扣よび（II）に ついては $4 \%$ 硫酸を用い封管中で $100^{\circ} \mathrm{C}$ で 8 時間加熱する方法 で（III）は $72 \%$ 硫酸に溶解して室温に 1 時間放肙したのち，水 を加えて硫酸を希釈し約 4\%とし，8時間沸騰浴中で加熱する方 法によって行なった。それぞれ加水分解液は炭酸バリウムを加之 て中和し，硫酸バリウムを口別し，Amberlite IR-120 および Amberlite IR-4 B のカラムを通じてウロン酸を除き減圧濃縮し た。このよ5にしてえた画分（Ｉ），（II）および（III）の加水分 解物についてペーパークロマトグラフィーを行なった結果, 確認 された単糖はキシロース，マンノース括よびグルコースのみで， ブタノールーピリジンー水（以下 $\mathrm{Bu}-\mathrm{P}-\mathrm{W}$ と略記する）を溶剤と して3回マルチプル・ジベロプメントによる展開を行ない,アニ リン水装フタル酸塩を発色剂として比色定量し, 構成単糖の含量 を定めた結果は表 1 に示すとおりである。

\begin{tabular}{|c|c|c|c|c|}
\hline \multirow[b]{2}{*}{ 画 分 } & \multicolumn{3}{|c|}{ 表 } & \multirow[b]{2}{*}{$\begin{array}{l}\text { グルコース:マンン } \\
\text { ース:キシロース }\end{array}$} \\
\hline & $\begin{array}{c}\text { グルロース } \\
(\%)\end{array}$ & $\begin{array}{c}\text { マンノース } \\
(\%)\end{array}$ & $\begin{array}{c}\text { キシロース } \\
(\%)\end{array}$ & \\
\hline I & 16 & 28 & 56 & $1: 1.7: 3.5$ \\
\hline II & 16 & 30 & 54 & $1: 1.9: 3.4$ \\
\hline III & 26 & 46 & 28 & $1: 1.8: 1.1$ \\
\hline
\end{tabular}

画分（II）および（III）のマンノース含量は前報1) のグルコ・ マンナンのマンノース含量よりやや大きい程度で大差が認められ ない。

\section{$2 \cdot 2$ マンナンのアセチル化}

III $2 \mathrm{~g}$ に少量の水を加えよく分散させ，多量のエタノールを加 えて遠心分離し， えられる沈殿物にピリジン $60 \mathrm{~m} l$ と無水酢酸 $40 \mathrm{ml}$ を加えて室温〜 $30^{\circ} \mathrm{C}$ で 2 日間アセチル化を行なった。酢化 液は遠心分離して不溶物を除いたのち，水中に投入して酢化物を 沈殿させ，口別し，水洗風乾した。この酢化物を $30 \mathrm{ml}$ のク口ロ ホルムに溶解し，これに石油エーテル的 $100 \mathrm{ml}$ を加えると白色 の粉末 $1.5 \mathrm{~g}$ が沈殿する（III-A とす）。

酢化液の遠心沈殿は，前と同様にしてさらに 2 日間酢化を行な い, 不溶物 $(1.1 \mathrm{~g} ，$ III-B とす) を遠心分離して上澄を水中に投 入したが，ほとんど沈殿はえられなかった。 III-B はクロロホル ムおよびアセトンに不溶であった。

III-A および III-B のアセチル価は， III-A 46.5\%， III-B 33.1 \%(ちなみにへキソザン・トリアセテートでは $44.8 \%$ ， ペント ザン・ジアセテートでは $39.8 \%$ となる)。また III-A クロロホ ルム溶液について，かりにトリアセチル・セルロースのクロロホ ルム溶液としての $K_{\mathrm{m}}$ の值 $5.3 \times 10^{-4}$ を使用して粘度法で分子 量を算出すると，その平均重合度は 60 となる。

つざに III-A 特よび III-B 約 $100 \mathrm{mg}$ をそれぞれ $72 \%$ 硫酸 を使用して前記と同様な方法で加水分解し, 炭酸バリウムで中和 し, Amberlite IR-120 および Amberlite IR-4 B を通じ, 減圧 濃縮したものについてペーパークロマトグラフィーを行なった。 その結果， III-B の加水分解液より検出された単糖はキシロース， マンノースおよびグルコースのみであるが， III-A の加水分解液 よりはこれらの 3 単糖のほかにラムノースと思われるスポットが 認められた。この試料について前報1)の方法によって定めた構成

\begin{tabular}{|c|c|c|c|c|}
\hline \multirow[b]{2}{*}{ 試 料 } & \multicolumn{3}{|c|}{ 表 $\quad 2$} & \multirow[b]{2}{*}{$\begin{array}{l}\text { グルコース:マンン } \\
\text { ース:キシロース }\end{array}$} \\
\hline & $\begin{array}{c}\text { グルコース } \\
(\%)\end{array}$ & マンノ์ース & $\begin{array}{c}\text { キシロ } \\
(\%)\end{array}$ & \\
\hline III-A & 31 & 49 & 20 & $1: 1.6: 0.6$ \\
\hline III-B & 26 & 42 & 32.0 & $1: 1.6: 1.2$ \\
\hline
\end{tabular}

単糖量を表示すると表 2 となる。

\section{$2 \cdot 3$ メチルペントース}

III-A の加水分解液にはラムノースの存在することが推定され るので，これの確認を行なった。トロロアオイの粘質物はグルコ 一ス，キシロース，アラビノース，ラムノース拈よ゙ガラクッロ ン酸より構成されている多糖であり ${ }^{5)}$ ，ペーパークロマトグラフ ィーでのラムノースの $R_{\mathrm{f}}$ 值はこの多糖については决定されてい るので，これとの対比によって，III-A のラムノースの决定を行 な打らとした。すなわち，町田ら5)の方法にしたがってトロロア オイを加水分解し，イオン交換樹脂を使用してウロン酸を除いた 試料と III-A の加水分解物とについて， Bu-P-W およびブタ， ール-酢酸-水（以下 $\mathrm{Bu}-\mathrm{Ac}-\mathrm{W}$ と略記する）を使用して，並べ てペーパークロマトグラフィーを行なった結果, 両者ともグルコ 一ス，キシロース，ラムノースに一致する $R_{\mathrm{f}}$ 值のスポットを与 えた。また Bu-P-W を溶剤として 3 回マルチプル・ジべロプメ ントを行なった結果も，両者ともラムノースに一致したスポット を与えた。これとは別に III-A について Oshima-Tollens のメ チルペントース反応6)を行ならと，明らかに陽性を示すから， III A にラムノースが含まれていることは明らかである。

\section{$2 \cdot 4$ ポリウロナイト}

パルプ $207 \mathrm{~g}$ を $4 \%$ 硫酸 $1.5 \mathrm{l}$ 中に常温で 2 日間浸漬したの ち, 10 時間還流下で煮沸して加水分解し，口液に水酸化パリウム および炭酸パリウムを加文硫酸根を除き，Amberlite IR-120 お。 よび Amberlite IR-4 B のカラムを通じ，この陰イオン交換樹脂 の方を 4\% 硫酸に一夜浸漬してウロン酸を溶出させ，口別し，炭 酸バリウムを加えて中和口別し，ふたたび Amberlite IR-120の カラムを通じ, 流出液を減圧濃縮して褐色のシロップをえた。こ のシロップをメタノールで抽出し，不溶物を除き，減圧下で濃縮 乾固し，ふたたびメタノールで抽出し，減圧濃樎してシロップと した。この操作をくり返して褐色のシロップ約 $50 \mathrm{mg}$ をえた。 このシロップの水溶液について Bu-P-W 拈よび Bu-Ac-W を 溶羭としてペーパークロマトグラフィーを行ない, アニリン水素 フタル酸塩およびアニリン・トリクロル酢酸塩を発色剈に用いる とウロン酸に相当する部分に 2 個のスポットのみがみられた。

$10 \times 40 \mathrm{~cm}$ の口秖を使用し， Bu-P-W を溶剤として，上記の ウロン酸のシロップを展開し，溶剂をさったのち，ウロン酸に相 当する $R_{\mathrm{f}}=0.10$ のスポット $(\mathrm{A})$ と $R_{\mathrm{f}}=0.05$ のスポット(B) の部分を切りとり， $A$ 部分は水で抽出し，ガラクッロン酸および グルクロン酸を対照として，Bu-P-W および Bu-Ac-W を溶㓮 とする展開を行ない, アニリン水素フタル酸塩で発色させると, ガラクッロン酸に一致し, 明らかにグルクロン酸とは区別される 1 個のスポットがみられた。Bu-Ac-W を溶剂とした場合にもウ ロン酸のスポットのみが認められ，そのラクトンのスポットは認 められなかった。グルクロン酸はこのクロマトグラフィーでは遊 離酸とそのラクトンの 2 個のスポットを与えることが知られてお

5) 町田, 内野, 日化 72, 917 (1951).

6) 日本化学会編, “害験化学講座”第 23 巻, p. 373 (昭 32 ). 
り，ガラクッロン酸は容易にラクトン化しないから7)，上の事実 からもAのウロン酸はグルクロン酸でないことは明らかである。 また4-0-methyl-glucuronic acid のようなグルクロン酸の誘導 体とも $R_{\mathrm{f}}$ 值は異なっているから，このウロン酸はガラクッロン 酸であると推定される。

B はアルドビウロン酸であることが予想されるので，4\% 硫酸 で抽出し，沸騰浴中で 2 時間加水分解し, 炭酸バリウムで中和し， 遠心分離した上澄液に $0.1 \mathrm{~N}$ 硫酸を滴下して, $\mathrm{pH}$ 約 5 とし, 生 ずる沈殿を遠心分離し，減圧濃樎して Bu-P-W を溶剤として， ペーパークロマトグラフィーを行なった結果はキシロースのスポ ットのみ認められ，ウロン酸は認められなかった。さらに別に 4 $\%$ 硫酸，また $2 \%$ 硫酸で抽出し，1時間加熱加水分解を試みた が，いずれの場合もキシロースのみが検出され，ウロン酸のスボ ットはみることができなかった。Bは陰イオン交換樹脂より脱着 されたものであるから，キシロースを含む中性のオリゴ糖とは考 えにくく，その $R_{\mathrm{f}}$ 值は文献値によるキシロースを含む重糖の $R_{\mathrm{f}}$ 值ともいちじるしく異なっているから，おとらくはキシロースと ガラクッロン酸よりなるアルドビウロン酸ではないかと思われ る。

$2.54 \%$ オルトホウ酸を含む $20 \%$ 水酸化カリウムによるパル プの抽出

赤松パルプ $130 \mathrm{~g}$ を，3時間窒素気流中で室温で $4 \%$ オルト ホウ酸を含む $20 \%$ 水酸化カリウム $2 l$ に浸漬したのち, 前記と 同様にしてフェーリング液を加え，生成するマンナン銅を常法に よって脱銅し，脱酸洗浄してえられるマンナンを $1 l$ の水を使用 し反復抽出して，できるだけ水溶性物質を除き，残留物は $10 \%$ 水酸化ナトリウムに溶解し，フェーリング夜を加えてふたたび、 ンナン銅を沈殿させた。同一の処理をくり返し，最後に白色の沈 殿物 $4.8 \mathrm{~g}$ をえた。

7) S. M. Partidge, Biochem. J. 42, 251 (1948).
この沈股を $72 \%$ 硫酸に溶解し，前記と同様に希釈して加熱加 水分解し, ウロン酸を除いたものの, 構成単糖としてはキシロー ス，マンノース拉よびグルコースが確認され，この三単糖を比色 定量した結果はキシロース 14\%，マンノース $61 \%$ ，グルコース $25 \%$ (ただしキシロース十マンノース十グルコース =100として) で, キシロース: マンノース:グルコース $=0.6: 2.5: 1.0$ であ る。

\section{6 dimethyl sulfoxide による抽出}

Öhrn $5^{8)}$ は, dimethyl sulfoxide を使用してパルプを抽出し, methyl glucurono-xylan のアセチル化物を戦離し, 越島 ${ }^{9)}$ は赤 松ホロセルロースを dimethyl sulfoxide で抽出して, 多量のマ ンナンとアセチル基をもつ抽出物をえたと報告している。赤松パ ルプ $80 \mathrm{~g}$ を試料とし，これを dimethyl sulfoxide $500 \mathrm{ml}$ に 1 冝夜室温で浸漬したのち, 王搾口過し, 口夜を $3 l$ のメタノール 中に注入して生じる沈殿を遠心分離し，メタノールで洗浄乾燥す ると灰白色の沈貶 $50 \mathrm{mg}$ がえられた。

この沈段物を $4 \%$ 硫酸とともに $100^{\circ} \mathrm{C}$ で 6 時間加水分解し， 常法によってペーパークロマトグラフィーを行なって構成単糖を 検索すると，多量のキシロースと極く少量のグルコースおよびウ ロン酸が検出された。また $72 \%$ 硫酸加水分解を行なった場合に は，多量のキシロースと極く少量のグルコースのみが確認され た。しかし，いずれの加水分解によっても相当量の不溶物が残留 することが認められ，非糖成分の混入していることを示した。こ の結果, 赤松パルプのヘミセルロースには易加水分解性の一種の グルコサンが存在することが予想される。

終りに御指導を睗わった京都大学田中正三教授に深甚な謝意を 表する。

8) O. E. Öhrn, I. Croom, Chem. Abst. 55, 983 (1961).

9) 越島，木材誌 6,194 (1960). 